\title{
EFFECTS OF SOLIDS CONCENTRATION AND SUBSTRATE TO INOCULUM RATIO ON METHANE PRODUCTION FROM FERMENTED ORGANIC MUNICIPAL SOLID WASTE
}

\author{
Mario F. Castellón-Zelaya * and Simón González-Martínez
}

Environmental Engineering Department, Institute of Engineering, National University of Mexico (Universidad Nacional Autónoma de México), 04510 Mexico City, Mexico

Article Info:

Received:

21 January 2021

Revised:

19 May 2021

Accepted:

24 May 2021

Available online:

30 June 2021

Keywords:

OFMSW

Methane production

Solids concentration

Inoculum

Fermentation

Storage

\begin{abstract}
The organic fraction of municipal solid waste (OFMSW) is usually stored under variable humidity conditions and extended periods before processing in anaerobic digestion plants. Digestate from previous batches is used as inoculum and mixed with previously stored (fermented) OFMSW for methane production under different substrate (OFMSW) to inoculum (digestate) ratios. Although both the moisture content during the storage of OFMSW and the inoculum concentration in the feed mixture to the anaerobic reactors are determining factors for the process, no studies were found on how these combined parameters affect methane production. This research is focused on determining how humidity affects OFMSW during storage (fermentation) and how the substrate to inoculum ratio affects the methanisation of the previously stored OFMSW. OFMSW with solids concentrations of 10,20 , and $28 \%$ was stored/fermented at $35^{\circ} \mathrm{C}$ for 15 days. The methanisation of the previously fermented OFMSW was allowed at $\mathrm{S} / \mathrm{I}$ ratios of $0.5,1.0$, and 1.5 . The fermentation results show that ethanol and acetic acid accounted for $90 \%$ of all products (metabolites). The lowest solids concentration allowed the highest fermentation degree with the highest VFA and alcohols production. Compared to fresh OFMSW, methane from fermented OFMSW increased $32 \%$, and the time required to reach the maximum methane production decreased between 11 and $40 \%$. For fermented OFMSW, the $\mathrm{S} / \mathrm{I}$ ratio of 1.0 is the best condition to produce methane. ANOVA shows that, independently of solid concentration during storage, the $S / I$ ratio is the main parameter to consider for methane production and reducing reaction times.
\end{abstract}

\section{INTRODUCTION}

In anaerobic digestion (AD) facilities, temporary storage of the organic fraction of municipal solid waste (OFMSW) is a necessary practice due to seasonal changes in the type of wastes, collection practices, the distance of the sources to the processing facility, limited capacity of collection and transport systems, and limited processing capacity (Worrell and Aarne, 2011). Storage takes place from the moment the OFMSW is produced and placed in containers at the generation sites (houses, shops, public spaces, among others), where organic material begins to decompose. Subsequently, depending on composition, humidity, and other environmental conditions during storage, different fermentation processes could occur (Nilsson et al., 2018). Within a short time of storage, readily biodegradable substances are rapidly transformed into volatile fatty acids (VFA) and alcohols, causing their accumulation. These processes need to be controlled appropriately to avoid inhibition during the subsequent methanogenic step (Fantozzi and Buratti 2011).

To reduce the risk of process failure by acidification during anaerobic digestion, controlled storage has been proposed as pretreatment. In this stage, the conversion of readily biodegradable substances is oriented to ethanol production rather than VFA (Wu et al., 2015). Ethanolic fermentation positively affects methane production because ethanol production consumes less alkalinity than VFA fermentation (Zhao et al., 2016). The ethanol fermentation path allows the methanogenic microorganisms to use chemical energy more efficiently (Pipyn and Verstraete, 1981). As a general concept, acid, and alcoholic fermentations before methanisation enable the control of specific process parameters and adjust operational conditions for increased subsequent methane production (Schievano et al., 2014).

In European countries, where the controlled storage (si- 
lage) of agricultural residues and energy crops to produce biogas is a common practice, studies show that controlled storage (silage), as a pretreatment before anaerobic digestion, allows the improvement of methane production from solid organic substrates (Pakarinen et al., 2011; Wang, 2010; Herrmann et al., 2011). Lü et al. (2016) consider mesophilic food waste storage as pretreatment to enhance methane production: They conclude that hydrolysis and subsequent methane production improve drastically with storage time (up to 12 days). Although OFMSW storage for weeks or even months is usual in biogas plants, no studies related to fermentation processes during storage have been found. OFMSW storage before processing in biogas plants in Europe, China, and other countries where industrial biogas production is standard is mandatory as the initial step of the whole process (Stürmer, 2017; Al Seadi et al., 2008; Qian et al., 2016.

Solids concentration is a critical parameter during silage. OFMSW arrives at the processing facilities under different humidity conditions, and the microbial dynamics and reaction kinetics depend on the bioavailability of water in the environment (Zhou et al., 2018; García-Bernet et al., 2011). Storage or silage is the previous step to methanisation. The concentration of the archaea responsible for this step is crucial as they are responsible for consuming VFA and avoiding alkalinity to drop below specific limits. Higher concentrations of methanogenic microorganisms are related to process stability; they can consume the previously produced VFA without allowing the media to become acid or decrease alkalinity beyond recovery (Hosseini et al., 2019). The main objective of this research deals with the effects of OFMSW storage (silage) under different solids concentrations and the consequences of silage on subsequent methane production.

\section{MATERIALS AND METHODS}

\subsection{OFMSW sampling and characterisation}

Three times a week, source-separated OFMSW is transported to the Coyoacán transfer station in Mexico City, where sampling was made according to ASTM D5231-92 (2016). Approximately $100 \mathrm{~kg}$ from 11 trucks were separated and thoroughly mixed using a skid-steer loader and shovels. Then, the quartering method was applied two times to reduce the bulk to approximately $200 \mathrm{~kg}$. Undesired materials, such as plastic bags, stones, and wood, were manually separated. The remaining "clean" OFMSW was distributed in two-liter freezing bags and frozen at $-20^{\circ} \mathrm{C}$. A sample of fresh OFMSW was characterized for $\mathrm{pH}$, total solids (TS), volatile solids (VS), COD, VFA, and ammonia nitrogen (NH4-N). VFA and $\mathrm{NH} 4-\mathrm{N}$ were determined in the liquid fraction after centrifugation. All determinations were made according to Standard Methods (APHA, 2017).

Table 1 shows the characteristics of fresh OFMSW. OFMSW contains $72 \%$ moisture and, from the total solids, $79 \%$ corresponds to volatile solids. Fresh OFMSW is naturally acid with a $\mathrm{pH}$ value of 5.2 and a VFA concentration of $10 \mathrm{gCOD} / \mathrm{kgVS}$. Determined as COD, $40 \%$ of OFMSW is soluble.
TABLE 1: Characteristics of the organic fraction of municipal solid waste.

\begin{tabular}{l|c|c}
\multicolumn{1}{c}{ Parameter } & Unit & Value \\
\hline $\mathrm{pH}$ & - & $5.2 \pm 0.1$ \\
\hline Humidity & $\%$ & $72 \pm 1.0$ \\
\hdashline $\mathrm{VS} / \mathrm{TS}$ & - & 0.79 \\
\hdashline Total COD & $\mathrm{g} / \mathrm{kg}_{\mathrm{TS}}$ & $1140 \pm 13$ \\
\hdashline Soluble COD & $\mathrm{g} / \mathrm{kg}_{\mathrm{TS}}$ & $445 \pm 9$ \\
\hline Total VFA & $\mathrm{g}_{\mathrm{COD}} / \mathrm{kg}_{\mathrm{TS}}$ & $8.0 \pm 0.5$ \\
\hline $\mathrm{NH}_{4}-\mathrm{N}$ & $\mathrm{g} / \mathrm{kg}_{\mathrm{TS}}$ & $1.7 \pm 0.1$ \\
\hline
\end{tabular}

\subsection{OFMSW fermentation}

Six batch reactors were operated at $35^{\circ} \mathrm{C}$ for 15 days, using $1,000 \mathrm{~mL}$ glass bottles with a reaction volume of 800 $\mathrm{mL}$. Shredded OFMSW was placed in the reactors, and total solids concentration (TS) was adjusted to 10,20 , and $28 \%$. The highest TS concentration corresponds to fresh OFMSW. To adjust the other solids concentrations, tap water was added. Three reactors with different solids concentrations were connected to an automated biogas monitoring system (AMPTS II, Bioprocess Control, Sweden), and the remaining three reactors were used for sampling. No mixing was performed in the reactors connected to the biogas monitoring system. The fermentation took place with the native microorganisms, and the $\mathrm{pH}$ was not adjusted at any time. In the sampling reactors, the content was mixed manually before obtaining samples. For every sample, determinations were made for total solids (TS), volatile solids (VS), soluble COD, ethanol, methanol, and VFA. VFA and alcohol concentrations were calculated based on the actual VS when samples were taken. The degree of acidification, or acidification rate (na), defined as the fraction of soluble COD converted to VFA, was calculated according to equation 1. To calculate the acidification degree, it is necessary to express the different determined VFA as COD equivalent. The sum of all VFA COD equivalents was divided by the total soluble COD of OFMSW.

According to Bolzonella et al. (2005) and Favaro et al. (2013), OFMSW contains enough naturally-occurring microorganisms to perform the anaerobic acid fermentation. Under this consideration, it was decided that supplementary inoculum for the fermentation was not necessary.

\subsection{Adaptation of methanogenic inoculum}

The inoculum used for the methanisation of the OFMSW fermentation products was digestate produced in the laboratory and adapted to OFMSW. For 58 days, a reactor was semi-continuously operated at $35^{\circ} \mathrm{C}$. The reactor was fed with the same fresh OFMSW used in the fermentation stage and was run under the following criteria: a) Bicarbonate alkalinity to total alkalinity ratio (a index) higher than 0.6 (Sun et al., 2016); b) VFA concentration was kept under $1.5 \mathrm{~g} / \mathrm{kgOFMSW}$ (Saveyn and Eder, 2014) and c) stable biogas production was considered when methane concentration was consistently over $60 \%$ in the biogas (Schievano et al., 2008). Before using the digestate for the methane production tests, it was kept under the same environmental conditions without feed for six days. 
TABLE 2: Experimental arrangement for the methanisation tests.

\begin{tabular}{c|c|c|c|c} 
& S/I ratio & Solids concentration during storage $\left(_{\text {TS }}\right.$ ) \\
& & $\mathbf{1 0}$ & $\mathbf{2 0}$ & $\mathbf{2 8}$ \\
\hline $\begin{array}{c}\text { Fermented } \\
\text { OFMSW }\end{array}$ & 0.5 & $\mathrm{R} 1$ & $\mathrm{R} 2$ & $\mathrm{R} 3$ \\
& 1.0 & $\mathrm{R} 4$ & $\mathrm{R} 5$ & $\mathrm{R} 6$ \\
\hline Fresh & 1.5 & $\mathrm{R} 7$ & $\mathrm{R} 8$ & $\mathrm{R} 9$ \\
OFMSW & 1.0 & $\mathrm{R} 13$ & $\mathrm{R} 14$ & $\mathrm{R} 15$ \\
& 1.5 & $\mathrm{R} 10$ & $\mathrm{R} 11$ & $\mathrm{R} 12$ \\
\hline
\end{tabular}

\subsection{Methanisation of fermented OFMSW}

For the methanisation, the substrate to inoculum (S/I) ratio was adjusted to $0.5,1.0$, and 1.5 as volatile solids to reach a reaction volume of $300 \mathrm{~mL}$ in $500 \mathrm{~mL}$ flasks. As a reference, another set of nine flasks was also placed in the temperature-controlled water bath and fed with fresh OFMSW instead of the fermented one (Table 2). Immediately after filling the flasks, the remaining air was washed out with nitrogen to guarantee anaerobic conditions. $\mathrm{pH}$ was not adjusted, and the experiment ran without buffer. Incubation took place at $35^{\circ} \mathrm{C}$, without mixing, for 25 days, connected to an automated biogas counter (AMPTS II, Bioprocess Control, Sweden). A control containing only the inoculum was also monitored to determine endogenous methane production. Methane concentration in the biogas was determined daily by gas chromatography.

The $\mathrm{S} / \mathrm{I}$ ratios for this research were selected according to articles reporting similar results. Di Maria et al. (2012) report that, for industrial OFMSW anaerobic digestion, lower $S / I$ ratios are common ( 0.3 to 0.5 , based on TS) in order to increase the methane production rates and to reduce malfunctioning risks. Karthikeyan and Visvanathan (2013) report values for successful batch dry anaerobic digestion of 10 to $60 \%$ inoculum (digestate from previous batches). Motte et al. (2013) conclude that S/I ratios between 2 and 6 can be managed in lab-operated reactors. Considering these reported results, the $S / I$ ratios selected for this research include variations.

\subsection{Analytical methods}

$\mathrm{pH}$, total COD, total (TS), volatile solids (VS), and ammonia nitrogen (NH4-N) were determined according to Standard Methods (APHA, 2017). Soluble COD was determined by photometry after $0.45 \mu \mathrm{m}$ filtration. $\mathrm{NH} 4-\mathrm{N}$ was determined in the liquid fraction after centrifugation with a relative centrifugal force (RCF) of $4704 \mathrm{xg}$ for 7 minutes $(5,000$ rpm, rotor diameter $16.7 \mathrm{~mm}$ ). Ethanol and VFA (acetic, propionic, isobutyric, butyric, isovaleric, valeric, and hexanoic acids) were determined using a gas chromatograph (HP 5890 GC System) equipped with flame ionization detector (FID), Stabilwax column - DA, with hydrogen as the carrier. The sample was previously filtered using $0.22 \mu \mathrm{m}$ cellulose filters. The biogas composition $\left(\mathrm{CO}_{2}\right.$ and $\left.\mathrm{CH}_{4}\right)$ was determined using a gas chromatograph (SRI 8610c) equipped with a thermal conductivity detector, stainless steel column packed with silica gel (8600-PK1A), helium as carrier gas with a $27 \mathrm{~mL} / \mathrm{min}$ flow rate. The detector temperature was $150^{\circ} \mathrm{C}$.

\subsection{Statistical analysis}

The experimental results of methane production and reaction time were analyzed using multiple linear regression, considering a confidence level of $95 \%$. Regression was used to make estimates or predictions for the dependent variables. The statistical analysis tool Solver for Excel was used.

\section{RESULTS AND DISCUSSION \\ 3.1 OFMSW fermentation \\ 3.1.1 Effects of solid concentration on $\mathrm{pH}$}

Figure 1.a shows the $\mathrm{pH}$ behavior for the different solids concentrations. Since $\mathrm{pH}$ was not controlled, during the first day, in all cases, there was a rapid decrease to values near 4 for the two higher TS and slightly under 4 for the lowest TS. In reactors with higher TS (20 and 28\%), pH did not vary significantly during the remaining 14 days. In the $10 \%$ TS reactor, $\mathrm{pH}$ dropped to values below 4.0 that can be attributed to lactic and formic acid formation, whose pKa values are 3.86 and 3.77, respectively (Xu et al., 2012). After day $6, \mathrm{pH}$ increased to values slightly over 4 , and it remained, with minor changes, until the end of the experiment. From those results, it can be concluded that $\mathrm{pH}$ decreases with decreasing solids concentration, at least during the first days. It has been reported that at low $\mathrm{pH}$ values, the fermentation of highly biodegradable substrates is limited. At such low $\mathrm{pH}$ values, VFA are in a dissociated form and can quickly diffuse through the cell membrane, lowering the internal $\mathrm{pH}$ and thus inhibiting cell activity (Warnecke and Gill, 2005). However, a positive aspect of low pH values is that, by inhibiting microbial activity, organic matter and energy losses are limited, allowing the preservation of the substrate during long periods and preserving the potential methane production (Wang, 2010; Jiang et al., 2013). Kalač (2012) evaluated the loss of organic matter during fermentation of energy crops, observing that, for total solids concentrations between 15 and $30 \%$, the losses were minimal when the $\mathrm{pH}$ values varied between 4.1 and 4.45 .

\subsubsection{Hydrolysis}

In all cases, on the first day of experimentation, soluble COD decreases (Figure 1.b). The heterogeneity of the substrate, together with the multiple and complex reactions during fermentation, makes that COD determinations cannot be as precise as desired. However, soluble COD's relative stability was observed from day 3 until the end of the experiment with average values of 301,373 , and $423 \mathrm{~g} /$ kgVS for solids concentrations of 10,20 , and $28 \%$, respectively. The acid conditions, with $\mathrm{pH}$ values between 3.9 and 4.1, inhibited the hydrolytic and other microorganisms' activity. According to Nizami Bern. (2009), effective hydrolysis can occur when $\mathrm{pH}$ values are between 5.5 and 6.5. At $\mathrm{pH}$ values lower than 5.0 , organic matter solubilization is limited (Zhou et al., 2018). In Figure 1.b, no tendency in the behavior of soluble COD can be observed. At the end of the fermentation, a reduction of volatile solids was observed: For the 10,20 , and $28 \%$ solids concentrations, the decrease was 12,14 , and $5 \%$, respectively. 

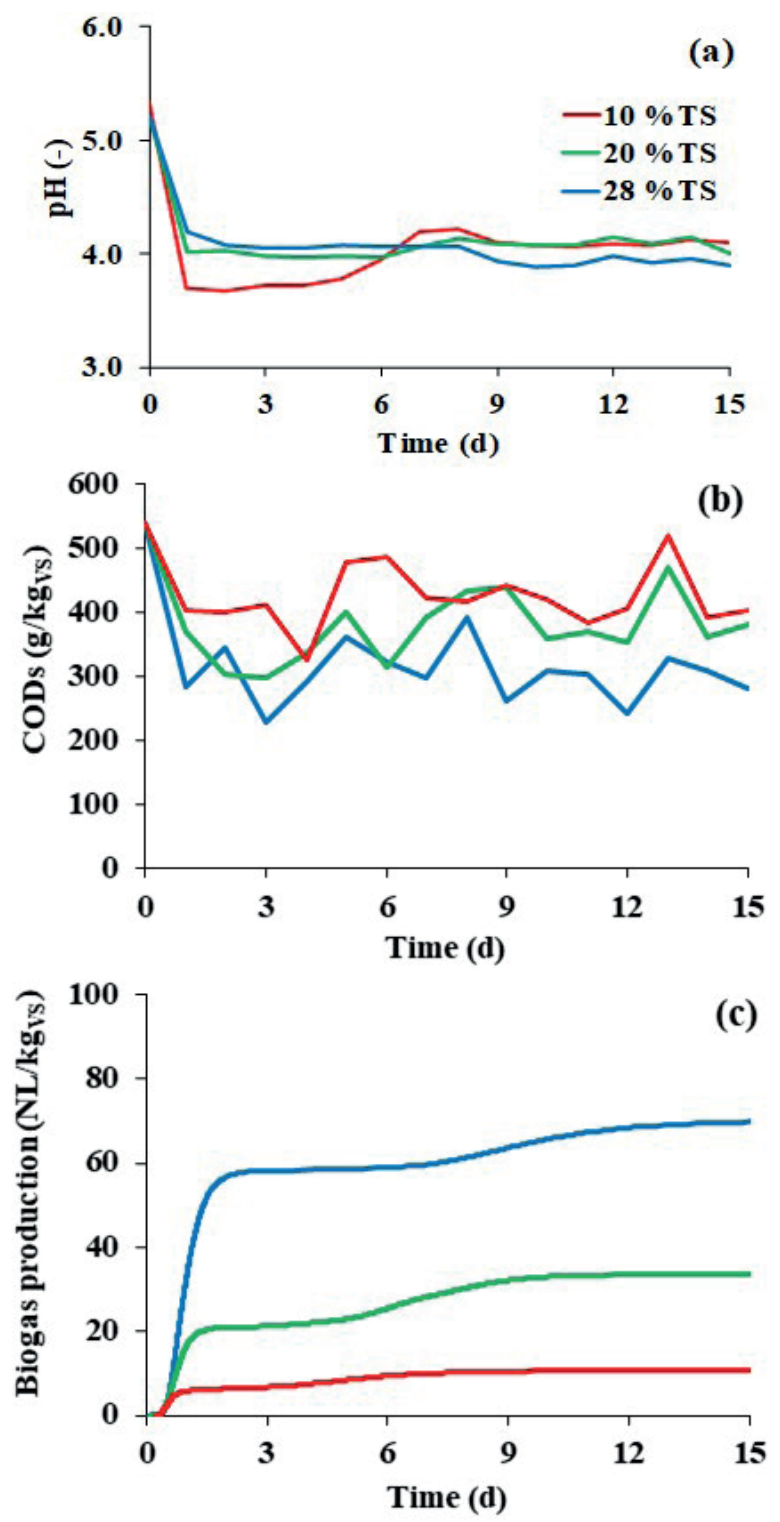

FIGURE 1: pH (a), soluble COD (b), and biogas production (c).

\subsubsection{Production of fermentation gases}

Figure 1.c also shows that the production of gases increased significantly during the first two days before the $\mathrm{pH}$ values decreased; this can also be compared with the sudden COD decrease during the same period. After the third day, $\mathrm{pH}$ and gases production stabilized because, as previously stated, lower $\mathrm{pH}$ values inhibited the biochemical activity. The higher gases production corresponds to the lower solids concentration.

\subsubsection{VFA and alcohols production}

Figure 2 shows that, for all three TS, total VFA production increased slowly and constantly until day 10 , and then it continued without significant variations. Figure 2 also shows that VFA concentrations increased with decreasing solids concentrations. The highest VFA concentration was recorded on day 9 with $133 \mathrm{gCOD} / \mathrm{kgVS}$ in the reactor with $10 \%$ TS while, for the reactors with 20 and $28 \%$ TS, the highest VFA concentrations were 91 and $56 \mathrm{gCOD} / \mathrm{kgVS}$, recorded at days 15 and 13 , respectively. The highest total VFA concentrations correspond to maximum acidification rates of 52,25 , and $15 \%$ for TS of 10,20 , and $28 \%$ TS, respectively. The acidification rates indicated in Figure 2, calculated at the end of the experiment for the initial soluble COD, are only $18 \%$ for $10 \%$ TS, $14 \%$ for $20 \%$ TS, and $7 \%$ for 28 TS: Acidification rates are inversely proportional to TS. This means that only a small fraction of OFMSW was transformed to VFA. These yields are lower than those reported in other articles where low $\mathrm{pH}$ is considered the inhibitor of acidogenic microorganisms (Wang et al., 2014). Silva et al. (2013) determined a maximum OFMSW acidification rate of $32 \%$ under mesophilic conditions and $\mathrm{pH}$-controlled at 6.0 .

With a different purpose, Moretto et al. (2019) evaluated VFA production from OFMSW under mesophilic conditions and at different $\mathrm{pH}$ values, reporting acidification rates of 55,79 , and $81 \%$ for $\mathrm{pH}$ of $5.0,7.0$, and 9.0 , respectively. These results confirm that the acidification rate is strongly dependent on $\mathrm{pH}$ and, to reach a maximum VFA yield, the $\mathrm{pH}$ needs to be controlled between 5.0 and 6.0 (Gottardo et al., 2015). At the same time as $\mathrm{pH}$ can act as an inhibitor, it is also an essential factor to determine the VFA composition during fermentation (Jiang et al., 2013), especially on the production of acetic, propionic and, butyric acids, whose formation is more sensitive to $\mathrm{pH}$ variations than other VFA (Liu et al., 2012). In this research, the primary acids produced were acetic, propionic, and butyric in all cases. The acetic acid in all three reactors represents more than $90 \%$ of the total VFA determined at the end of the experiment. This a positive feature considering that acetate is the preferred substrate by methanogens. In the reactor with $10 \%$ TS (Figure 2.a), greater diversity on VFA production was observed as valeric, and hexanoic acids were also present. Two phases of fast VFA production were identified: The first peak at the end of day 2 resulted in an increase of approximately four times the acetic acid concentration to the initial value. Ethanol production also increased about five times its concentration during the first two days. Zoetemeyer (1982) states that lower pH values favor the production of long-chain fatty acids. The second phase of acetic acid production can be associated with two processes: Firstly, acetogenesis from ethanol can be observed as acetic acid concentration increases and ethanol concentration decreases (reactors with 20 and 28\%TS) or increased fast during the first two days, as in the case of the reactor with $10 \%$ TS (Figure 2.a). Secondly, VFA with more than three carbons were transformed through acetogenesis and made acetic acid concentrations increase. Yuan et al. (2006) report that, during anaerobic fermentation, VFA with more than three carbons are easily degraded to form acetic acid. For the two lower TS concentrations, acetic acid production increased steadily while, for the highest TS concentration, the increase was slower. In all three cases, after day 10 , acetic acid production practically stopped and remained almost unchanged until the end of the experiment.

After acetic acid, propionic acid accounted for the most significant VFA fraction. As with acetic acid, propionic acid 

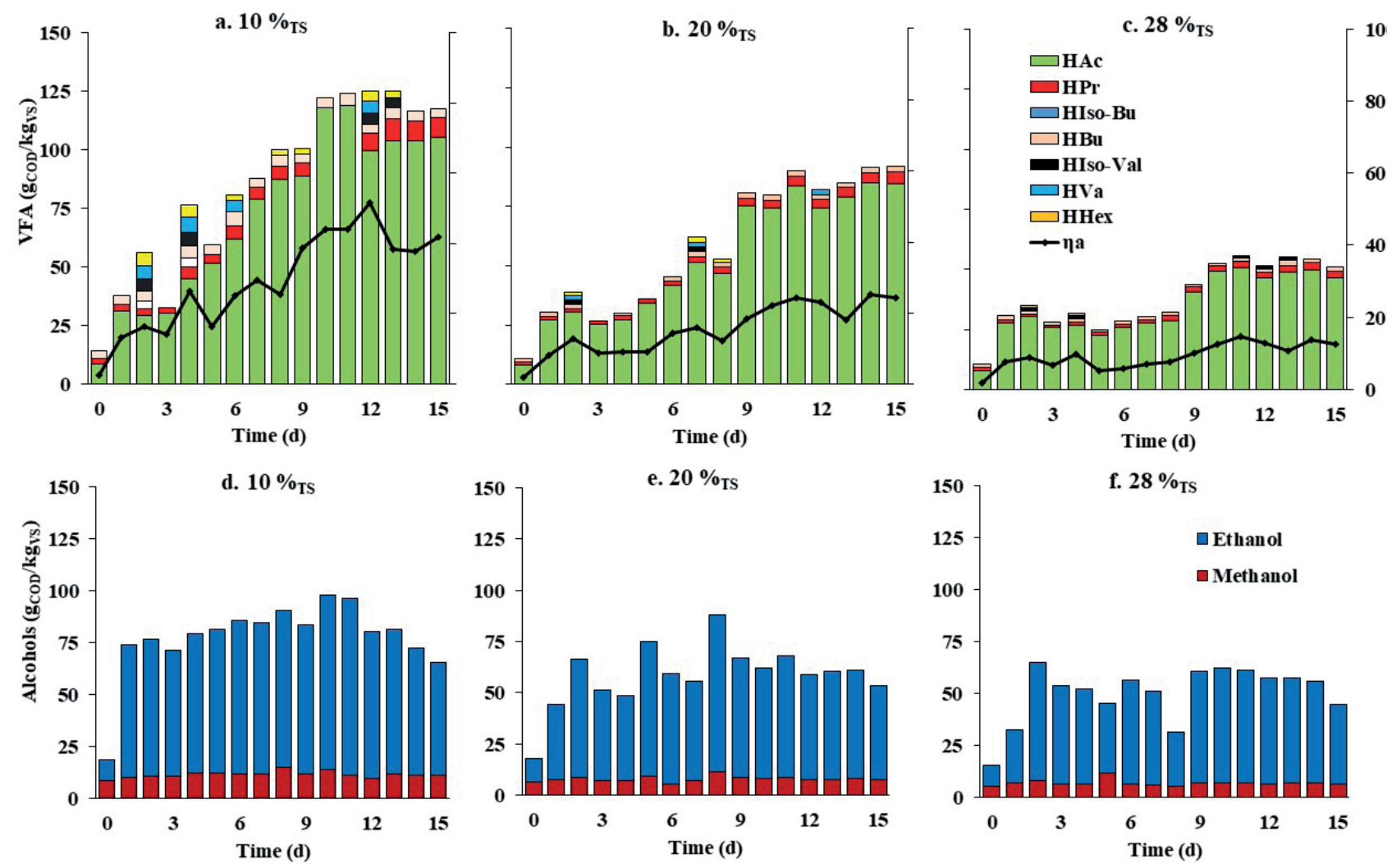

FIGURE 2: VFA and alcohol production, and acidification rate (na). HAc (acetic acid), HPr (propionic acid), HIsoBu (isobutyric acid), HBu (butyric acid), HIso-Va (isovaleric acid), HVa (valeric acid), HHex (hexanoic acid).

concentration was inversely proportional to TS concentration. This concurred with another study where propionic acid concentration increased as TS decreased, and $\mathrm{pH}$ was low (4.0 to 4.5) (Wang et al. 2014). Propionic acid accumulated at lower $\mathrm{pH}$ values. Thermodynamically, higher hydrogen partial pressure inhibits acetogenic microorganisms, and propionate cannot be processed: During anaerobic digestion, hydrogen and acetate are consumed to form mainly and $\mathrm{CO}_{2}$ making that acetogenesis runs continuously (Henze et al., 2008). Butyric acid represents the third largest VFA fraction. Its concentration did not change significantly over time because, as with propionic acid, acetogenic microorganisms were inhibited and could not process butyric acid.

Ethanol and methanol production was also monitored (Figure 2). In all cases, during the first two days of fermentation, a rapid increase in ethanol production together with $\mathrm{H} 2$ and $\mathrm{CO} 2$ production could be observed. The fast gases production (Figure 1.c) was also observed during this same period. He et al. (2012) report similar results; they studied the hydrolysis and acidification of food waste at $35^{\circ} \mathrm{C}$ with $18 \% \mathrm{TS}$ and finding that ethanol and acetic acid constituted $99 \%$ of the metabolites after seven days of fermentation. Dogan et al. (2009) report that during OFMSW fermentation with $25 \% \mathrm{TS}$, ethanol and acetic acid were the primary metabolites produced when the $\mathrm{pH}$ value ranged between 3.5 and 4.0. Figure 2 shows that the lack of soluble carbohydrates can explain the ethanol concentration's relative stability after day 3 as the particulate material's hydrolysis decreased. Also, lower $\mathrm{pH}$ values inhibit the metabolism of alcohol-producing bacteria or yeast.

On day 11, the maximum ethanol concentration in the reactor with $10 \% \mathrm{TS}$ (Figure 2.d) was $84 \mathrm{gCOD} / \mathrm{kgVS}$ while, for reactors with 20 (Figure 2.e) and 28\%TS (Figure 2.f), the maximum ethanol concentrations were 58 and $59 \mathrm{gCOD} /$ $\mathrm{kgVS}$, respectively. The highest ethanol concentration was recorded in the reactor with the lowest solids concentration. For the three reactors, ethanol represents $52 \%$ of the total concentration of metabolites in terms of abundance. The production showed no significant variations over the whole experiment (Figure 2). Methanol also was determined. Methanol is an essential final product from pectin metabolism (Schink and Zeikus 1980), which is part of the cell walls of most fruits and vegetables found in OFMSW. The methanol concentration did not change significantly over time, and this can be explained as this metabolism product cannot further develop under stress, such as low $\mathrm{pH}$ values. Also, any other organisms can use it as substrate under these conditions.

\subsection{Methanisation of fermented OFMSW}

\subsubsection{Adaption of inoculum}

To produce an adapted inoculum for the methanisation tests, a batch reactor was operated with a mixture of OFMSW and anaerobic granular sludge at a ratio of 0.5 gVS OFMSW per gram VS of granular sludge. As shown in Figure 3.a, in the mixture of OFMSW with the granular sludge, both $\mathrm{pH}$ and alkalinity ratio ( $\mathrm{a}$ index) resulted in val- 
ues considered adequate for methanogenesis (Sun et al., 2016). From the start, the VFA concentration in the reactor increased, presenting the highest concentration on day 6 , but without negatively affecting the methanogenic activity; at this time, the methane concentration in the biogas was over $60 \%$ (Figure 3.b). The highest methane production rate was recorded during the first 6 days. After day 25, the methane production continued increasing at a slow regular rate until the end of the experiment.

The reactor was operated for 48 days until the parameters considered adequate for an adapted inoculum were met. The digestate used to seed the OFMSW for methane production had an a index of 0.8 , and total VFA concentration of $5.0 \mathrm{gCOD} / \mathrm{kgVS}$. The biogas had a methane concentration of $64 \%$, complying with the criteria to be considered an adequate inoculum.

\subsubsection{Methane production}

To evaluate their methane production, every one of the OFMSW fermentation products from the experiments at 10,20 , and $28 \%$ TS were inoculated with the adapted methanogenic digestate to adjust substrate to inoculum ratios (S/I, as volatile solids) to $0.5,1.0$, and 1.5 (Figure 4). The characteristics of the adapted digestate used as inoculum were $\mathrm{pH}=8.3$, humidity $=89 \%$; VS $/ \mathrm{TS}=0.73$; total COD = $340 \mathrm{~g} / \mathrm{kgVS}$; NH4-N = $31 \mathrm{~g} / \mathrm{kgVS}$. Fresh OFMSW was used as control. Shortly after mixing the different substrates with inoculum, the $\mathrm{pH}$ stabilized to values near 7 (Table 3). Mixing the adapted inoculum $(\mathrm{pH}$ 8.3) with fresh and fermented OFMSW caused the overall acidic $\mathrm{pH}$ values to increase to values near neutrality. For all cases, the initial $\mathrm{pH}$ values decrease as the $\mathrm{S} / \mathrm{I}$ ratio increases, and the reactors with fermented OFMSW showed lower $\mathrm{pH}$ values than the ones with fresh OFMSW. Although the initial $\mathrm{pH}$ values decreased according to solids concentration, they cannot be considered potential inhibitors. During the reaction, $\mathrm{pH}$ increased to values slightly alkaline, indicating healthy methanisation. Figure 4 shows the methane production curves for all 18 combinations indicated in Table 3.

The initial slopes for fresh OFMSW are slightly higher than those for fermented OFMSW and, after several days, the final methane production and the reaction times for fermented OFMSW are higher than for fresh OFMSW. At the reactions' end, the $\mathrm{pH}$ values were near 8.0 in all cases, meaning that the $\mathrm{pH}$ drop at the beginning could have influenced the process. However, methanogenesis consumed VFA rapidly, preventing $\mathrm{pH}$ from being an inhibitor.

The lower $S / I$ ratios produce methane rapidly during the first 3 to 4 days, and then, the reaction reaches an end to continue as endogenous methane production (Figure 4). Fresh OFMSW finishes methane production (359 NL/ kgVS) earlier than fermented OFMSW, and their final values are lower than those of fermented OFMSW (410 NL/kgVS) (Table 4). The curves corresponding to the S/I $=0.5$ (Figure 4.a) produce methane slower than those with the lower substrate concentration: the methane production from fermented OFMSW runs until day 9 , and, after day 10 , the production is caused by endogenous substrates. For $S / I=1.0$ (Figure 4.b) and fresh OFMSW, during the first six days, the curves run parallel to those of fermented OFMSW and finish earlier than those of fermented OFMSW. The methane production curves for $S / I=1.5$ (Figure 4.c) behave differently than the other two cases: Methane production is slower and takes more than 15 days to finish; fresh OFMSW with the highest $\mathrm{S} / \mathrm{I}$ requires more than 23 days to complete. Independent of the TS concentration, Figure 4 shows that, for $S / I=0.5$ and 1.0 , the initial slopes are practically the same for all curves and that the end of methane production is different for every one of them. It is important to note that all curves display the same performance for $S / I=0.5$ and 1.0 , with only one stage during methane production. For $\mathrm{S} /$ $I=1.5$, the curves present similar behavior, but with different values; differently than the other two $S / I$ values, for $S / I=1.5$, the highest TS concentrations report the highest methane yields where fermented OFMSW produce more methane than fresh OFMSW. The curves for $S / I=1.5$ present two stages, where the first and second stages end faster for the higher TS concentrations than for the lower ones.

Table 4 shows that fermented OFMSW with $10 \%$ TS and $S / I=1.0$ resulted in the most significant difference compared to fresh OFMSW with $99 \mathrm{NL} / \mathrm{kgVS}$ (32\% more for fermented than for fresh OFMSW). The next most significant difference is in reactors with $20 \% \mathrm{TS}$ and $\mathrm{S} / \mathrm{I}=1.0$ with $30 \%$ more methane production for fermented than for fresh OFMSW. These results conclude that the S/I ratio of 1.0 , the same amount of fermented OFMSW and inoculum, is
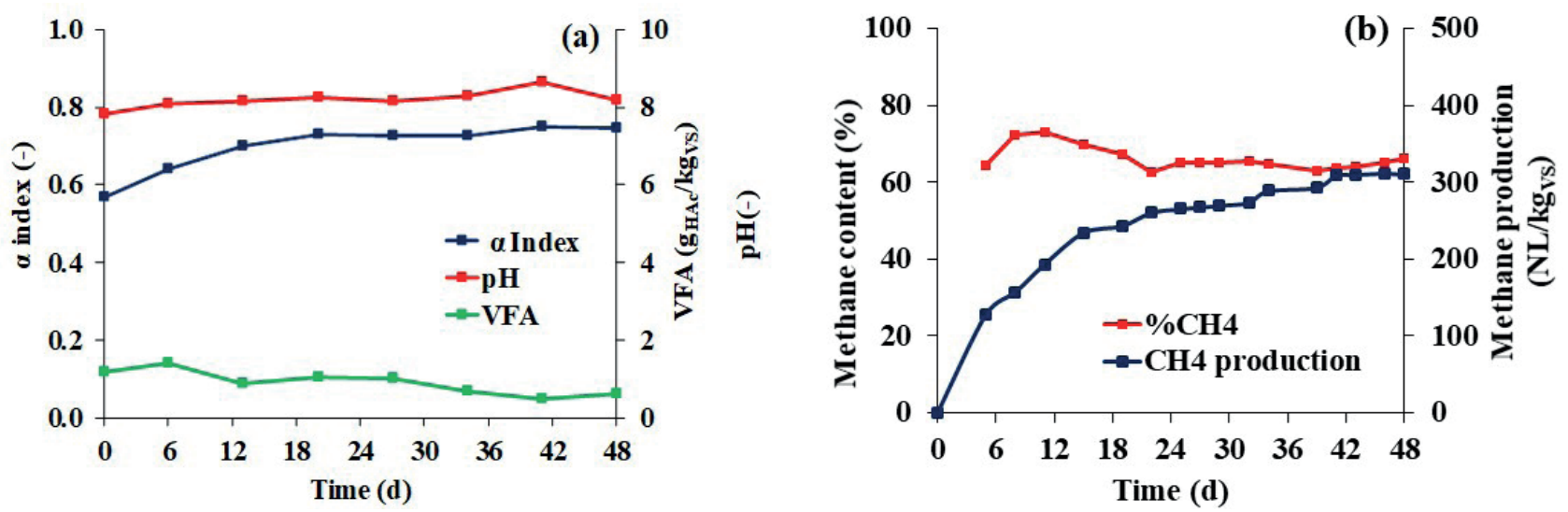

FIGURE 3: Behaviour of reactor operational parameters during inoculum adaptation. 
TABLE 3: $\mathrm{pH}$ values in the combinations of fermented and fresh OFMSW with adapted methanogenic inoculum.

\begin{tabular}{|c|c|c|c|c|c|}
\hline \multirow{2}{*}{$\%_{\text {TS }}$} & \multirow{2}{*}{ S/I ratio } & \multicolumn{2}{|c|}{ Fermented OFMSW } & \multicolumn{2}{|c|}{ Fresh OFMSW } \\
\hline & & Initial & Final & Initial & Final \\
\hline \multirow{3}{*}{10} & 0.5 & 7.0 & 8.2 & 7.6 & 8.2 \\
\hline & 1.0 & 6.8 & 8.1 & 7.3 & 8.1 \\
\hline & 1.5 & 6.3 & 7.3 & 7.2 & 8.1 \\
\hline \multirow{3}{*}{20} & 0.5 & 6.8 & 8.2 & 7.6 & 8.3 \\
\hline & 1.0 & 6.2 & 8.1 & 7.3 & 8.1 \\
\hline & 1.5 & 5.8 & 8.1 & 7.1 & 8.1 \\
\hline \multirow{3}{*}{28} & 0.5 & 6.9 & 8.2 & 7.6 & 8.2 \\
\hline & 1.0 & 6.3 & 8.2 & 7.3 & 8.1 \\
\hline & 1.5 & 6.0 & 8.0 & 7.1 & 8.2 \\
\hline
\end{tabular}
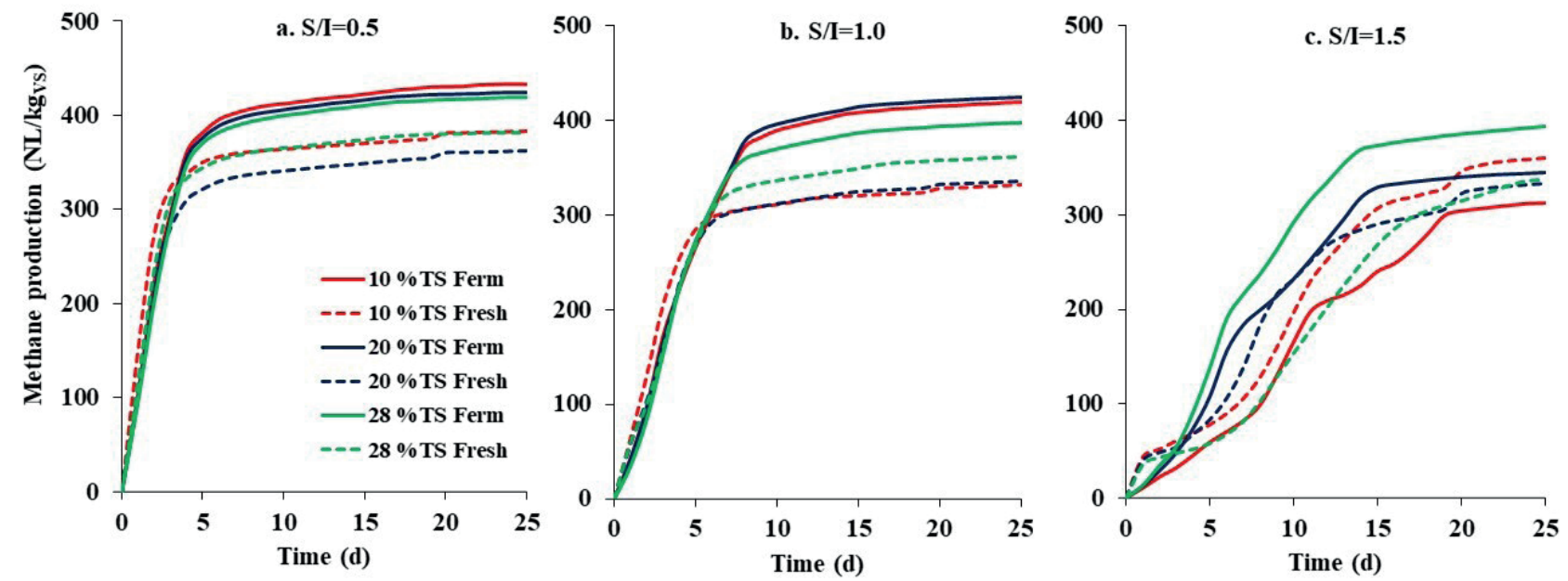

FIGURE 4: Specific methane production of fermented OFMSW (Ferm) and fresh OFMSW (Fresh) for 25 days according to different S/I ratios and TS.

the best combination of all the ones tested. Methanisation at low $\mathrm{S} / \mathrm{I}$ ratios of fermented OFMSW resulted in reaction time reductions between 11 and $40 \%$ compared to fresh OFMSW. These results show that fermentation of OFMSW increases the subsequent methane production and, at the same time, decreases the reaction time. Fermented OFMSW with the highest $S / I$ ratio of 1.5 reports the lowest methane production and the highest reaction time when compared to fresh OFMSW: the increase in reaction time is proportional to solids concentration with 9,29 , and $56 \%$ for 10,20 , and $28 \%$ TS, respectively.

The lowest solids concentration during silage is responsible for the highest methane production, indicating that decreasing VS during silage did not significantly affect the subsequent methane production (Table 4). Borreani et al. (2018) observed similar behaviour in a system with decreasing organic matter; they report VS losses of $20 \%$ and no decreases in methane production.

Table 4 shows the methane production from fermented and fresh OFMSW for the different TS concentrations and S/I ratios. According to Holliger et al. (2016), the reaction finishes when methane production values do not variate more than $1 \%$ as an average of three consecutive days. The reaction time corresponds to the time needed for the reaction to finish. According to Figure 3 and Table 4, meth- ane production of fermented OFMSW improved between 2 and $32 \%$ compared to fresh OFMSW. In only one case, the reactor with $10 \% \mathrm{TS}$ and $\mathrm{S} / \mathrm{I}=1.5$, methane production was lower for fermented OFMSW than for fresh OFMSW in $14 \%$. Similar results were reported by Schievano et al. (2014); they determined an increase between 23 and $43 \%$ in energy recovery through methane production in the process of anaerobic co-digestion of corn silage and fruit and vegetable residues in a two-stage process. Liu et al. (2006) observed $21 \%$ increase in methane production from the digestion of domestic solid waste in batch reactors operated in two stages. On the other hand, Voelklein et al. (2016) recorded an increase of $23 \%$ when they used food as a substrate for digestion in a two-stage methanogenic reactor.

Figure 5 shows the methane production rates (slopes from curves in Figure 3 ) according to the substrate to inoculum ratio and substrate concentration. The slopes for 20 and $28 \%$ TS for fermented OFMSW are similar without significant differences between them, indicating that no differences in methane production rate can be differentiated from one another (compare with Figure 4). Coincidentally, for fermented OFMSW, all three lines cross at a S/I ratio of 1.0 , proving that the previously proposed conclusion that the $S / I$ ratio of 1.0 is the best condition to produce methane. The lowest solids concentration behaves differently: it 
TABLE 4: Methane production and reaction time of fermented and fresh OFMSW.

\begin{tabular}{|c|c|c|c|c|c|c|}
\hline \multirow{2}{*}{$\%_{\text {TS }}$} & \multirow{2}{*}{$\begin{array}{c}\mathrm{S} / \mathrm{I} \\
\text { ratio }\end{array}$} & \multicolumn{2}{|c|}{ Methane production $\left(\mathrm{NL} / \mathbf{k g}_{\mathrm{vs}}\right)$} & \multirow{2}{*}{$\Delta \mathrm{CH}_{4}$ production (\%)* } & \multicolumn{2}{|c|}{ Reaction time (d) } \\
\hline & & Fermented OFMSW & Fresh OFMSW & & Fermented OFMSW & Fresh OFMSW \\
\hline \multirow{3}{*}{10} & 0.5 & 410 & 359 & +14 & 7 & 9 \\
\hline & 1.0 & 408 & 309 & +32 & 9 & 15 \\
\hline & 1.5 & 306 & 357 & -14 & 23 & 21 \\
\hline \multirow{3}{*}{20} & 0.5 & 403 & 338 & +19 & 8 & 9 \\
\hline & 1.0 & 404 & 312 & +30 & 10 & 12 \\
\hline & 1.5 & 335 & 328 & +2 & 22 & 17 \\
\hline \multirow{3}{*}{28} & 0.5 & 397 & 363 & +9 & 9 & 9 \\
\hline & 1.0 & 377 & 336 & +12 & 10 & 12 \\
\hline & 1.5 & 376 & 337 & +12 & 25 & 16 \\
\hline
\end{tabular}

${ }^{\star}$ Represents the variation in methane production of fermented OFMSW compared to fresh OFMSW

has a higher slope, meaning that lower $\mathrm{S} / \mathrm{I}$ ratios produce methane more rapidly than higher S/I ones when the S/I ratio is under 1.0. When $\mathrm{S} / \mathrm{I}$ ratios and solids concentrations are high, methane can be produced less rapidly as solids concentrations increase.

Figure 5 indicates that, for fresh OFMSW, the methane production rates are different that fermented OFMSW. The lines cross at the highest $\mathrm{S} / \mathrm{I}$ ratio, indicating deficient methane production at higher substrate concentrations. As expected, the rates increased with decreasing $\mathrm{S} / \mathrm{I}$ ratios and, among the three tested fresh OFMSW concentrations, the lowest, corresponding to $10 \% \mathrm{TS}$, present higher methane production rates.

Higher methane production from fermented OFMSW can be explained as a function of the acidification rate. The higher the acidification rate, the higher is the methane production reached under lower substrate concentrations. The metabolites produced during fermentation are readily available for methanogenic archaea. Fresh OFMSW does not have metabolites from fermentation. Similar processes are reported by Buffière et al. (2018), who investigated the hydrolysis of cattle slurry and corn silage mixtures in two-stage systems: They found that, after $48 \mathrm{~h}$ of hydrolysis, the methane production increased significantly, and concluded that in a two-stage anaerobic digestion process, first-stage fermentation improved the substrate availability to methanogens. The use of inoculum adapted to the substrate has proven to be a determining factor in achieving higher methane yields (Campuzano, 2015; Brown and Murphy, 2013). In this study, the adapted inoculum was responsible for higher methane production rates.

\subsection{Regression analysis}

The results were analyzed using multiple linear regression to determine the influence of the operational parameters over methane production and reaction time. ANOVA significance test for methane production from fermented OFMSW shows that, for a p-value higher than 0.05 , solids concentration, as \%TS, does not significantly contribute to methane production and reaction times. The results show too that, for a $\mathrm{p}$-value lower than 0.05 , the substrate to inoculum ratio, $\mathrm{S} / \mathrm{I}$, is the most critical parameter. This means
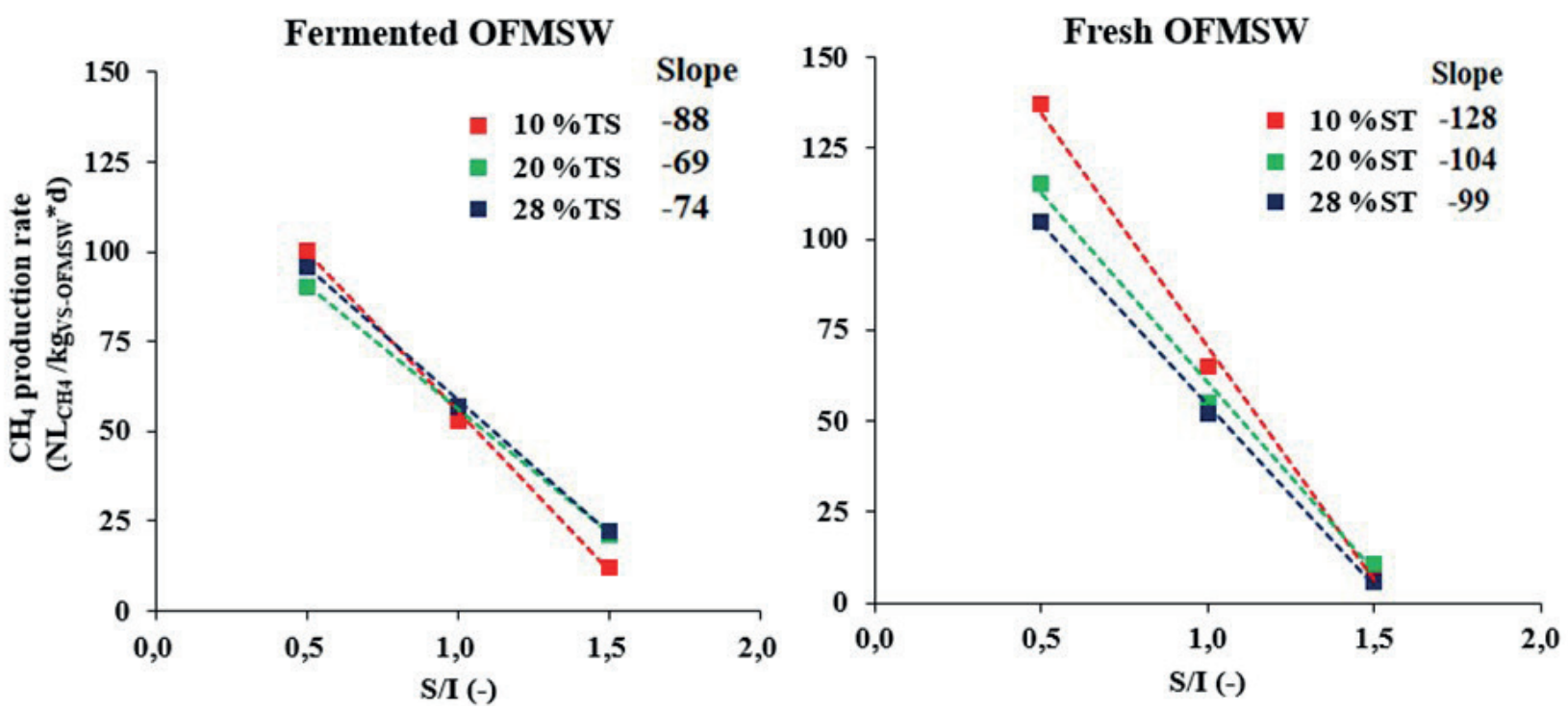

FIGURE 5: Methane production rates according to the substrate to inoculum ratio, S/I, and TS. 
that, independently of solids concentration during OFMSW fermentation, when using high inoculum concentrations for methanisation of fermented OFMSW, methane production increases, and the reaction time decreases. The lowest p-value obtained for the reaction time was 0.002 , and it shows that methanisation of fermented OFMSW at a low S/I ratio has more importance than reducing the reaction time.

For fresh OFMSW methanisation, p-value were 0.500 and 0.898 for $\mathrm{S} / \mathrm{I}$ and $\% \mathrm{TS}$, respectively. When $\mathrm{p}$-values are higher or equal to the significance value, then these parameters have no significant influence over methane production from fresh OFMSW. For lower reaction times, the analysis shows the p-value for $\mathrm{S} / \mathrm{I}$ and \%TS of 0.000 and 0.036 , respectively. The meaning of these values is that lower S/I ratios allow a faster VFA uptake and other metabolites during the methanisation of fresh OFMSW without increasing methane production. Several authors report that solids concentration significantly affects methane production (Fernández et al., 2008; Dong et al., 2010; Abbassi-Guendouz et al., 2012; Campuzano, 2015). However, they do not consider the influence of inoculum concentration. These authors conclude that higher methane yields can be obtained with increasing solids concentration. Uncertainty arises from the results of Forster-Carneiro et al. (2008). They also experimented with fresh OFMSW varying the concentrations of both substrate and inoculum concentrations, concluding that the reactors with lower substrate concentrations produce more methane; unfortunately, they do not make any comments on the combined effects of the two variables.

\section{CONCLUSIONS}

During OFMSW fermentation, VFA and alcohol production increased with decreasing solids concentration. Together acetic acid and ethanol constitute more than $90 \%$ of all metabolites. OFMSW fermentation allowed 32\% more methane production for the lowest solids concentrations than for fresh OFMSW, indicating that the VS loss during fermentation does not affect subsequent methane production. For fermented OFMSW, the S/I ratio of 1.0 is the best condition to produce methane. Methanisation of fermented OFMSW at low $\mathrm{S} / \mathrm{I}$ ratios resulted in reaction times reductions between 11 and $40 \%$ than fresh OFMSW. Methane production from fermented and fresh OFMSW increased substantially with a decreasing substrate to inoculum, S/I, ratios. Independently of substrate solids concentrations, high inoculum concentrations increase methane production and reduce methanisation times.

\section{ACKNOWLEDGMENTS}

This research was carried out at the Environmental Engineering Laboratory, Institute of Engineering, National University of Mexico. The authors want to thank also Dr. Óscar González-Barceló for his support in laboratory techniques and academic advisory during the whole project.

Funding: This work was funded by the Mexican Centre for Innovation in Bioenergy - Cluster for Gaseous Biofuels, (Centro Mexicano de Innovación en Energía), CONACYT project Nr. 247006; and the General Directorate for Academic Affairs (Dirección General de Asuntos del Personal Académico, DGAPA) of the National University of Mexico (UNAM), project IT101320.

\section{REFERENCES}

Abbassi-Guendouz, A., Brockmann, D., Trably, E., Dumas, C., Delgenès, J-P., Steyer, J-P., Escudié R., 2012. Total solids content drives high solid anaerobic digestion via mass transfer limitation. Bioresour. Technol. 111, 55-61. https://doi.org/10.1016/j. biortech.2012.01.174

Al Seadi, T., Rutz, D., Prassl, H., Köttner, M., Finsterwalder, T., Volk, S and Janssen, R., 2008. Biogas Handbook. University of Southern Denmark. Esbjerg, Denmark

APHA, 2017. Standard methods for the examination of water and wastewater, 23rd edition. American Public Health Association, Washington, D. C.

ASTM D5231-92, 2016. Standard Test Method for Determination of the Composition of Unprocessed Municipal Solid Waste, ASTM International, West Conshohocken, PA.

Bolzonella, D., Fatone, F., Pavan, P., Cecchi, F., 2005. Anaerobic fermentation of organic municipal solid wastes for the production of soluble organic compounds. Ind. Eng. Chem. Res. 44 (10), 3412-3418. https://doi.org/10.1021/ie048937m

Borreani, G., Tabacco, E., Schmidt, R. J., Holmes, B. J., Muck, R. E., 2018. Silage review: Factors affecting dry matter and quality losses in silages. J. Dairy Sci. 101, 3952-3979. https://doi.org/10.3168/ jds.2017-13837

Browne, J., Murphy, J., 2013. Assessment of the resource associated with biomethane from food waste. Appl. Energy 104, 170-177. https://doi.org/10.1016/j.apenergy.2012.11.017

Buffière, P., Dooms, M., Hattou, S., Benbelkacem, H. 2018. The hydrolytic stage in high solids temperature phased anaerobic digestion improves the downstream methane production rate. Bioresour. Technol. 259, 111-118. https://doi.org/10.1016/j.biortech.2018.03.037

Campuzano, R., 2015. Lixiviación de residuos sólidos orgánicos urbanos para incrementar la rapidez de producción de biogás (Leaching of urban organic solid waste to increase the speed of biogas production). Doctoral thesis. National University of Mexico, Mexico City. Available in http://www.ptolomeo.unam.mx:8080/ xmlui/handle/132.248.52.100/7989 (in Spanish)

Di Maria, F., Sordi, A., Micale, C., 2012. Optimization of solid anaerobic digestion by inoculum recirculation: The case of an existing Mechanical Biological Treatment plant. Appl. Energy. 97, 462-469. https://doi.org/10.1016/j.apenergy.2011.12.093

Dogan, E., Dunaev, T., Ergude, T. H., Demirer, G. N., 2009. Performance of leaching bed reactor converting the organic fraction of municipal solid waste to organic acids and alcohols. Chemosphere 74, 797-803. https://doi.org/10.1016/j.chemosphere.2008.10.028

Dong, L., Zhenhong, Y., Yongming, S., 2010. Semi-dry mesophilic anaerobic digestion of water sorted organic fraction of municipal solid waste (WS-OFMSW). Bioresour. Technol. 101, 2722-2728. https:// doi.org/10.1016/j.biortech.2009.12.007

Fantozzi, F., Buratti, C., 2011 Anaerobic digestion of mechanically treated OFMSW: Experimental data on biogas/methane production and resiudes chracterization. Bioresour. Technol. 102, 8885-8892. https://doi.org/10.1016/j.biortech.2011.06.077

Favaro, L., Alibardi, L., Lavagbolo, M. C., Casella, S., Basaglia, M. 2013 Effects of inoculum and indigenous microflora on hydrogen production from the organic fraction of municipal solid waste. Int. J. Hydrog. Energy. 38, 11774 - 11779. https://doi.org/10.1016/j. ijhydene.2013.06.137

Fernández, J., Pérez, M., Romero, L. 2008. Effect of substrate concentration on dry mesophilic anaerobic digestion of organic fraction of municipal solid waste (OFMSW). Bioresour. Technol. 99, 60756080. https://doi.org/10.1016/j.biortech.2007.12.048

Forster-Carneiro, T., Pérez, M., Romero, L., 2008. Influence of total solid and inoculum contents on performance of anaerobic reactors treating food waste. Bioresour. Technol. 99, 6994-7002. https:// doi.org/10.1016/j.biortech.2008.01.018

García-Bernet, D., Buffière, P., Latrille, E., Steyer, J. P., Escudi, R., 2011. Water distribution in biowastes and digestates of dry anaerobic digestion technology. Chem. Eng. J. 172, 924-928. https://doi. org/10.1016/j.cej.2011.07.003 
Gottardo, M., Micolucci, F., Mattioli, A., Faggian, S., Cavinato, C., Pavan, P., 2015. Hydrogen and methane production from biowaste and sewage sludge by two phases anaerobic codigestion. Chem. Eng. Trans. 43, 379-384. https://doi.org/10.3303/CET1543064

He, M., Sun, Y., Zou, D., Yuan, H., Zhu, B., Li, X., Pang, Y., 2012. Influence of temperature on hydrolysis acidification of food waste. Procedia Environ. Sci. 16, 85-94. https://doi.org/10.1016/j. proenv.2012.10.012

Henze, M., Van Loosdrecht, M., Ekama, G., Brdjanovi, D., 2008. Biological Wastewater Treatment: Principles, Modeling and Design. IWA Publishing, London.

Herrmann, C., Heiermann, M., Idler, C., 2011. Effects of ensiling, silage additives and storage period on mehtane formation of biogas crops. Bioresour. Technol. 102, 5153-5161. https://doi. org/10.1016/j.biortech.2011.01.012

Holliger, C., Alve, M., Andrade, D. Angelidaki, I., 2016. Toward a standarization of biomethane potential tests. Water Sci. Technol. 74, 2515-2522. DOI:10.2166/wst.2016.336

Hosseini, E., Azizi, A., Bazyar Lakeh, A. A., Hafez, H., Elbeshbishy, E., 2019. Comparison of liquid and dewatered digestate as inoculum for anaerobic digestion of organic solid wastes. Waste Manage. 87, 228-236. https://doi.org/10.1016/j.wasman.2019.02.014

Jiang. J., Zhang, Y., Li, K., Wang, Q., Gong, C., Li, M. 2013. Volatile fatty acids production from food waste: Effects of $\mathrm{pH}$, temperature, and organic loading rate. Bioresour. Technol. 143, 525-530. https:// doi.org/10.1016/j.biortech.2013.06.025

Kalač, P., 2012. The required characteristics of ensiled crops used as a feedstock for biogas production: a review. J. Agrobiol. 28, 85-96. DOI: 10.2478/v10146-011-0010-y

Karthikeyan, O. P., Visvanathan, C., 2013. Bio-energy recovery from high-solid organic substrates by dry anaerobic bio-conversion processes: A review. Reviews in Environ. Sci. Biotechnol. 12 (3), 257-284. doi.org/10.1007/S11157-012-9304-9

Le Hyaric, R., Chardin, C., Benbelkacem, H., Bollon, J., Bayard, R., Escudié, R., Buffière, P., 2012. Influence of moisture content on the specific methanogenic activity of dry mesophilic municipal solid waste digestate spiked with propionate. Bioresour. Technol. 102, 822-827. https://doi.org/10.1016/j.biortech.2010.08.124

Liu, D., Liu, D., Zeng, R., Angelidaki, I., 2006. Hydrogen and methane production from household solid waste in the two-stage fermentation process. Water Res. 40, 2230-2236. https://doi.org/10.1016/j. watres.2011.11.047

Liu, H., Wang, J., Liu, X., Fu, B., Chen, J., Yu, H-Q., 2012. Acidogenic fermentation of proteinaceous sewage sludge: Effect of $\mathrm{pH}$. Water Res. 46, 799-807. https://doi.org/10.1016/j.watres.2006.03.029

Lü, F., Xu, X., Shao, L., He, P., 2016. Importance of storage time in mesophilic anaerobic digestion of food waste. J. Environ. Sci. 45, 76-83. https://doi.org/10.1016/j.jes.2015.11.019

Moretto, G., Valentino, F., Pava, P., Majone, M., Bolzonella, D., 2019. Optimization of urban waste fermentation for volatile fatty acids production. Waste Manage. 92, 21-29. https://doi.org/10.1016/j. wasman.2019.05.010

Motte, J.-C., Escudié, R., Bernet, N., Delgenes, J.-P., Steyer, J.-P., Dumas, C., 2013. Dynamic affect od total solid content, low substrate/ inoculum ratio and particle size on solid-state anaerobic digestion. Bioresour. Technol. 144, 141-148. https://doi.org/10.1016/j. biortech.2013.06.057

Nilsson, S., Hellman, E., Moestedt, J., 2018. The effect of temperature storage time and collection method on biomethane potential of source separated household food waste. Waste Manage. 71, 636 643 DOI: 10.1016/j.wasman.2017.05.034

Nizami, A. S., Korres, N. E., Murphy, J. D., 2009. Review of the integrated process for the production of grass biomethane. Environ. Sci. Technol. 43, 8496-8508. DOI: 10.1021/es901533j

Pakarinen, A., Maijala, P., Jaakkola, S., Stoddard, F., Kymäläinen, M., Viikari, L., 2011. Evaluation of preservation methods for improving biogas production and enzymatic conversion yields of annual crops. Biotechnol. Biofuels 2011, 4:20. doi:10.1186/1754-6834-4-20

Pipyn, P., Verstraete, W., 1981. Lactate and ethanol as intermediates in two-phase anaerobic digestion. Biotechnol. Bioeng. 23, 1145 1154. https://doi.org/10.1002/bit.260230521

Qian, M. Y., Li, R. H., Li, J., Wedwitschka, H., Nelles, M., Stinner, W., Zhou, H. J., 2016. Industrial scale garage-type dry fermentation of muicipal solid waste to biogas, Bioresour. Technol. 217, 82-89. https:// doi.org/10.1016/j.biortech.2016.02.076
Saveyn, H., Eder, P., 2014. End-of-waste criteria for biodegradable waste subjected to biological treatment (compost \& digestate): Technical Proposals. JRC Scientific and Policy Reports, Sevilla. Available in: https://publications.jrc.ec.europa.eu/repository/bitstream/JRC87124/eow\%20biodegradable\%20waste\%20final\%20 report.pdf

Schievano, A., Pognani, M., D’Imporzano, G., Adani, F., 2008. Predicting anaerobic biogasification potential of ingestates and digestates of a full-scale biogas plant using chemical and biological parameters. Bioresour. Technol. 99, 8112-8117. https://doi.org/10.1016/j.biortech.2008.03.030

Schievano, A., Tenca, A., Lonati, S., Manzini, E. Adani, F., 2014. Can two-stages instead of one-stage anaerobic digestion really increase energy recovery from biomass? Appl. Energy 124, 335-342. DOI: 10.1016/j.apenergy.2014.03.024

Schink, B., Zeikus, J. G., 1980. Microbial methanol formation: A major end product of pectin metabolism. Curr. Microbiol. 4, 387-389. DOI: 10.1186/s40064-016-3303-1

Silva, F. C., Serafim, L. S., Nadais, H., Arroja, L., Capela. I., 2013. Acidogenic fermentation towards valorisation of organic waste streams into voiatile fatty acids. Chem. Biochem. Eng. 27, 467-476. Available in: https://hrcak.srce.hr/112368

Stürmer, B., 2017. Feedstock change at biogas plants - Impact on production costs. Biomass Bioenergy. 98, 228-235. https://doi. org/10.1016/j.biombioe.2017.01.032

Sun, H., Wu, Sh., Dong, R., 2016. Monitoring Volatile Fatty Acids and Carbonate Alkalinity in Anaerobic Digestion: Titration Methodologies. Chem. Eng. Technol. 34 (4) 599-610. https://doi.org/10.1002/ ceat.201500293

Voelklein, M. A., Jacob, A., O’ Shea, R., Murphy, J. D., 2016. Assessment of increasing loading rate on two-stage digestion of food waste. Bioresour. Technol. 202, 172-180. https://doi.org/10.1016/j.biortech.2015.12.001

Wang, G., 2010. Biogas production from energy crops and agriculture residues. Doctoral Thesis. Technical University of Denmark, Roskilde. Available in: https://backend.orbit.dtu.dk/ws/files/5179971/ ris-phd-72.pdf (in English)

Wang, K., Yin, J., Shen, D., Li, N., 2014. Anaerobic digestion of food waste for volatile fatty acids (VFAs) production with different types of inoculum: Effect of pH. Bioresour. Technol. 161, 395-401. https://doi.org/10.1016/j.biortech.2014.03.088

Warnecke, T., Gill, R. T., 2005. Organic acid toxicity, tolerance, and production in Escherichia coli biorefining applications. Microb. Cell Fact. 4, 1-8. DOI: 10.1186/1475-2859-4-25

Worrell, A., Aarne, P., 2011. Solid Waste Engineering, second ed. CENGAGE Learning, Stamford

Wu, C., Wang, Q., Yu, M., Zhang, X., Song, N., Chang, Q., Gao, M. Sonomoto, K., 2015. Effect of ethanol pre-fermentation and inoculum-to-substrate ratio on methane yield from food waste and distillers' grains. Appl. Energy 155, 846-853. https://doi. org/10.1016/j.apenergy.2015.04.081

Xu, S., Karthikeyan, P., Selvam, A., Wong, J., 2012. Effect of inoculum to substrate ratio on the hydrolysis and acidification of food waste in leach bed reactor. Bioresour. Technol. 126, 425-430. https://doi. org/10.1016/j.biortech.2011.12.059

Yuan, H., Chen, Y., Zhang, H., Jiang, S., Zhou, Q., Gu, G., 2006. Improved bioproduction of short-chain fatty acids (SCFAs) from excess sludge under alkaline conditions. Environ. Sci. Technol. 40, 20252029. DOI: 10.1021/es052252b

Zeotemeyer, R. J., Arnoldy, P., Cohen, A., Boelhouwer, C., 1982. Influence of temperature on the anaerobic acidification of glucose in a mixed culture forming part of a two-stage digestion process. Wate Res. 16, 313-321. https://doi.org/10.1016/0043-1354(82)90191-9

Zhao, N., Yu, M., Wang, Q., Song, N., Che, S., Wu, C., Sun, X., 2016. Effect of ethanol and lactic acid pre-fermentation of putrefactive bacteria suppression, hydrolysis, and methanogenesis of food waste. Energy Fuels 30, 2982-2989. https://doi.org/10.1021/acs.energyfuels.5b02779

Zhou, M., Yan, B., Wong, J., Zhang, Y., 2018. Enhanced volatile fatty acids production from anaerobic fermentation of food waste: A mini-review focusing on acidogenic metabolic pathways. Bioresour. Technol. 248, 68-78. https://doi.org/10.1016/j.biortech.2017.06.121 